\title{
Integrasi teknologi dalam pendidikan jasmani: peluang untuk menjawab krisis identitas dan legitimasi? ${ }^{1}$
}

\author{
Hysa Ardiyanto \\ Pascasarjana Universitas Negeri Yogyakarta \\ hysaardiyanto@gmail.com
}

\begin{abstract}
Abstrak. Krisis identitas dan legitimasi dalam Pendidikan Jasmani yang pernah dilontarkan di awal abad ke-21 dinilai memiliki kaitan dengan teknologi. Dalam hal tertentu Pendidikan Jasmani dan teknologi dapat dilihat dalam hubungan yang saling bertentangan. Pada perkembangannya, penggunaan teknologi untuk meningkatkan kualitas pendidikan dinilai telah menjadi standar bagi semua mata pelajaran, tidak terkecuali Pendidikan Jasmani. Tulisan ini berusaha melihat literatur-literatur dengan topik integrasi teknologi dalam Pendidikan Jasmani. Pembahasan meliputi dua hal utama, yaitu teknologi dalam proses pembelajaran Pendidikan Jasmani dan teknologi dalam pengembangan guru Pendidikan Jasmani. Asumsinya, ketika teknologi dapat diintegrasikan dalam proses pembelajaran dan penyiapan guru, maka akan muncul peluang untuk mengadvokasi hasil pembelajaran sehingga berpotensi menjawab krisis identitas dan legitimasi dalam Pendidikan Jasmani.
\end{abstract}

Kata kunci: Integrasi teknologi, Pendidikan Jasmani, Identitas dan legitimasi

\begin{abstract}
The crisis of identity and legitimacy in Physical Education that was proclaimed at the beginning of the 21 st century was viewed to be related with technology. Physical education and technology can be perceived as having a

\footnotetext{
${ }^{1}$ Artikel ini telah dipublikasikan di Prosiding Seminar Nasional Implementasi Riset dan Literasi untuk Meningkatkan Keterampilan Abad XXI oleh Keluarga Mahasiswa Pascasarjana Universitas Negeri Yogyakarta. Cetekan pertama Desember 2018.
} 
conflicting relationship in particular aspects. In its development, the use of technology to improve the quality of education has become a standard for all subjects, including Physical Education. This paper attempts to look at literature on topics regarding technological integration in Physical Education. The discussion involves two main things, namely technology in Physical Education's learning process and technology in the development of Physical Education teachers. The assumption is that when technology can be integrated in the learning process and teacher preparation, there will be opportunities to advocate learning outcomes. And in doing so, it has potensial to answer the crisis of Physical Education's identity and legitimacy.

Keywords: Technological integration, Physical Education, Identity and legitimacy

\section{PENDAHULUAN}

Tantangan yang dihadapi oleh Pendidikan Jasmani sebagai dampak dari perkembangan teknologi sangat nyata. Tidak jarang teknologi dianggap membawa dampak negatif bagi peserta didik dalam persoalan kurangnya gerak. Penggunaan gawai sebagai media teknologi digital yang berkorelasi dengan kurangnya gerak tubuh anak ditemui pada anak usia dini yang belajar di PAUD (Paramitha \& Anggara, 2018). Pada satuan pendidikan yang lebih tinggi juga tampaknya terjadi fenomena yang serupa. Kondisi semacam ini kemudian mendesak Pendidikan Jasmani untuk memberikan respon, mengingat gerak badan merupakan salah satu pokok pembelajaran dalam Pendidikan Jasmani. Sayangnya, dalam seminar atau konferensi yang mengangkat tema teknologi sebagai karakteristik abad ke-21 di Tanah Air, sedikit ditemui sumbangan pemikiran dari Pendidikan Jasmani.

Di sisi lain, peningkatan keterampilan abad ke-21 dalam dunia pendidikan dengan isu-isu seperti inovasi, riset, dan pemanfaatan teknologi semakin menguat. 
Para guru hari ini dihadapkan dengan tantangan yang cukup besar untuk memenuhi kebutuhan siswa generasi baru yang tidak pernah mengenal kehidupan tanpa komputer, konsol video-game, telepon seluler, atau akses internet. Ini merupakan tantangan yang secara dramatis mengubah ruang lingkup pendidikan (Krause, Franks, \& Lynch, 2017). Penggunaan teknologi untuk meningkatkan kualitas pendidikan pun dinilai telah menjadi standar bagi semua mata pelajaran, tidak terkecuali Pendidikan Jasmani. Namun demikian, karena sifat dasar ruang kelasnya yang unik, ada beberapa hal yang mungkin membuat implementasi teknologi pada Pendidikan Jasmani menjadi tidak mudah. Teknologi dan Pendidikan Jasmani kadang diposisikan pada ujung yang spektrum pendidikan berlawanan, yang satu dianggap kurang membutuhkan gerak sedangkan yang lain harus melalui gerak (Pyle \& Esslinger, 2014). Hal ini sepertinya membuat relasi antara Pendidikan Jasmani dengan teknologi terlihat tidak kompatibel.

Pada masa sebelumnya, teknologi dan Pendidikan Jasmani dianggap berpotensi mengalami benturan dalam persaingan legitimasi. Krisis identitas dan legitimasi dalam Pendidikan Jasmani yang pernah dilontarkan di awal abad ke-21, salah satunya, didorong oleh adanya desakan untuk penyelenggaraan mata pelajaran baru semacam teknologi informasi (Setiawan, 2004). Perkembangan teknologi yang direspon dengan menambah alokasi waktu mata pelajaran untuk keterampilan teknologi (informasi dan komunikasi) berpotensi mengorbankan alokasi waktu mata pelajaran lain. Pendidikan Jasmani pun berada di posisi kritis untuk digusur. Setelah lebih dari satu dasawarsa, apakah Pendidikan Jasmani dapat menjawab gugatan tersebut dengan memanfaatkan potensi yang terdapat pada teknologi? 


\section{PEMBAHASAN}

Teknologi sebagai kata kunci dalam upaya membangun identitas dan legitimasi dalam Pendidikan Jasmani dapat dilihat dari tiga hal. Pertama, terkait dengan persaingan dalam satuan mata pelajaran seperti sudah disinggung sebelumnya. Kedua, dalam hal tindakan belajar di mana penggunaan teknologi (khususnya informasi dan komunikasi) dinilai dapat merebut fungsi seorang guru pendidikan sebagai fasilitator siswa dalam belajar. Krisis dalam Pendidikan Jasmani tidak lepas dari pandangan bahwa banyak guru pendidikan jasmani yang tidak terlalu berkomitmen dan terdorong untuk "mengajar" sebagai suatu yang esensial dari usaha pendidikan jasmani. Ketiga, teknologi (bersama dengan kultur dan demografi) dianggap sebagai sub-konteks di mana Pendidikan Jasmani diselenggarakan. Dari ketiga sub-konteks itulah legitimasi pentingnya Pendidikan Jasmani mulai digarap (Setiawan, 2004).

Respon Pendidikan Jasmani terhadap perubahan di abad ke-21 salah satunya diwujudkan dalam pertemuan tingkat dunia "Global Forum for Physical Education Pedagogy" GoFPEP 2010 yang diadakan di Grundy Center, Iowa, Amerika Serikat. Pada forum tersebut teknologi menjadi salah satu penekanan selain isu "standar" seperti keterikatan dengan komunitas, kerjasama antar stakeholder, dan upaya menggali bentuk-bentuk pedagogi Pendidikan Jasmani serta metode-metode dalam mempersiapkan guru Pendidikan Jasmani (Edginton, Chin, Geadelmann, \& AhrabFard, 2011). Pembahasan dalam tulisan ini berangkat dari pernyataan konsensus forum tersebut dengan mengangkat isu (1) teknologi dalam proses pembelajaran Pendidikan Jasmani serta (2) teknologi dan penyiapan guru Pendidikan Jasmani, sehingga dapat dijadikan argumen dalam (3) advokasi hasil Pendidikan Jasmani. 


\section{Teknologi dalam pembelajaran Pendidikan Jasmani}

Pada dasarnya teknologi dinilai dapat diterapkan untuk membantu guru Pendidikan Jasmani dalam proses pembelajaran yang meliputi: persiapan rencana pengajaran, manajemen kelas, komunikasi dengan orang tua dan siswa, pembuatan instruksi dan umpan balik, serta penilaian (Adkins, Bice, Worrell, \& Unruh, 2017). Secara umum sudah dikenal teknologi yang digunakan dalam membantu guru Pendidikan Jasmani mulai dari stopwatch hingga alat yang canggih seperti heart rate monitors. Selain itu, sebagaimana mata pelajaran lain, dalam persiapan mengajar guru Pendidikan Jasmani dapat memanfaatkan internet, kemudian dalam pengarsipan data dan nilai menggunakan piranti lunak dalam komputer, serta menggunakan media pembelajaran video dalam penyajian materi pembelajaran. Pengunaan teknologi dengan cara seperti ini dalam Pendidikan Jasmani relatif tidak berbeda dengan mata pelajaran lainnya.

Penelitian Krause, Franks, \& Lynch (2017) menunjukkan bahwa topik teknologi yang paling sering dibahas dalam Pendidikan jasmani di Amerika Serikat adalah pengukuran aktivitas (activity monitors), gawai (mobile devices) dan media sosial. Pengukuran aktivitas bisa dikatakan sebagai salah satu topik khas yang dimiliki oleh Pendidikan Jasmani. Sementara itu tema-tema utama yang muncul pada pembahasan teknologi dalam Pendidikan Jasmani meliputi berjaringan dan berbagi sumber daya (networking and sharing resources), mengimplementasikan teknologi untuk mengajar, pemilihan teknologi, serta solusi atas pengumpulan dan manajemen data. Menariknya, penelitian ini menunjukkan bahwa para pendidik profesional sadar dan tertarik untuk mengimplementasikan berbagai teknologi ke dalam proses pembelajaran, namun mereka masih tidak yakin dalam bagaimana memilih, mengelola, dan mengimplementasikannya. Situasi yang hampir sama muncul pada 
studi Brenner dan Brill (2016) yang menunjukkan bahwa para calon guru merasa cukup mahir dengan teknologi dasar, tetapi tidak memiliki pengalaman yang cukup dengan teknologi yang lebih maju, meskipun mereka menunjukkan pandangan yang positif terhadap integrasi teknologi dalam pengajaran.

Persoalan inilah yang kemudian diangkat oleh Mishra dan Koehler (2006) ketika muncul kecenderungan dalam pendidikan untuk melihat hanya pada teknologi namun kurang menyentuh aspek bagaimana teknologi tersebut digunakan. Mereka berargumen perlunya sebuah kerangka secara teori dan konsep untuk memahami bagaimana menggunakan (infusing) teknologi dalam pendidikan. Kerangka yang saat ini berkembang dan diminati oleh para peneliti dan pendidik adalah technological pedagogical content knowledge (TPACK). Kerangka TPACK dikembangkan dari pedagogical content knowledge (PCK) yang dicetuskan oleh Lee Shulman. Ketika PCK pertama kali dikembangkan, isu-isu teknologi bukannya tidak dianggap penting, namun kehadirannya tidak seperti saat ini. Ruang kelas tradisional pada dasarnya menggunakan berbagai teknologi mulai dari buku teks, mesin ketik, tabel periodik di dinding laboratorium sampai proyektor. Hanya saja sebagian besar teknologi terebut sudah menjadi hal yang biasa dan bahkan tidak dianggap sebagai teknologi. Berbeda dengan saat ini, di mana semakin umum ditemui penggunaan teknologi yang mengacu pada komputer digital dan perangkat lunak komputer dengan mekanisme yang kadang sama sekali baru dan belum pernah ditemui sebelumnya.

Pertanyaan utama yang mendorong lahirnya kerangka TPACK adalah bagaimana guru dapat mengintegrasikan teknologi ke dalam pembelajaran mereka. Upaya integrasi ini harus secara kreatif dirancang atau terstruktur untuk dapat digunakan sesuai dengan karakteristik (baik materi maupun metode pengajaran) mata pelajaran tertentu dalam konteks situasi kelas yang spesifik. Dalam inti pembelajaran 
menggunakan teknologi yang baik terdapat tiga komponen pokok: konten, pedagogi, dan teknologi, ditambah hubungan di antara ketiga komponen. Interaksi antara ketiga komponen, menunjukkan perbedaan yang beragam dalam berbagai konteks yang menggambarkan kualitas integrasi teknologi pendidikan. Ketiga basis pengetahuan ini (konten, pedagogi, dan teknologi) membentuk inti dari kerangka TPACK (Koehler \& Mishra, 2009). Kerangka yang dikembangkan ini memberi pemahaman bahwa mengajar merupakan aktivitas kompleks yang perlu memanfaatkan banyak jenis pengetahuan. Artinya teknologi tidak serta merta diinfuskan ke dalam proses pembelajaran, melainkan membutuhkan suatu kerangka secara teori dan konsep seperti TPACK. Kerangka TPACK dapat dilihat pada gambar 1:

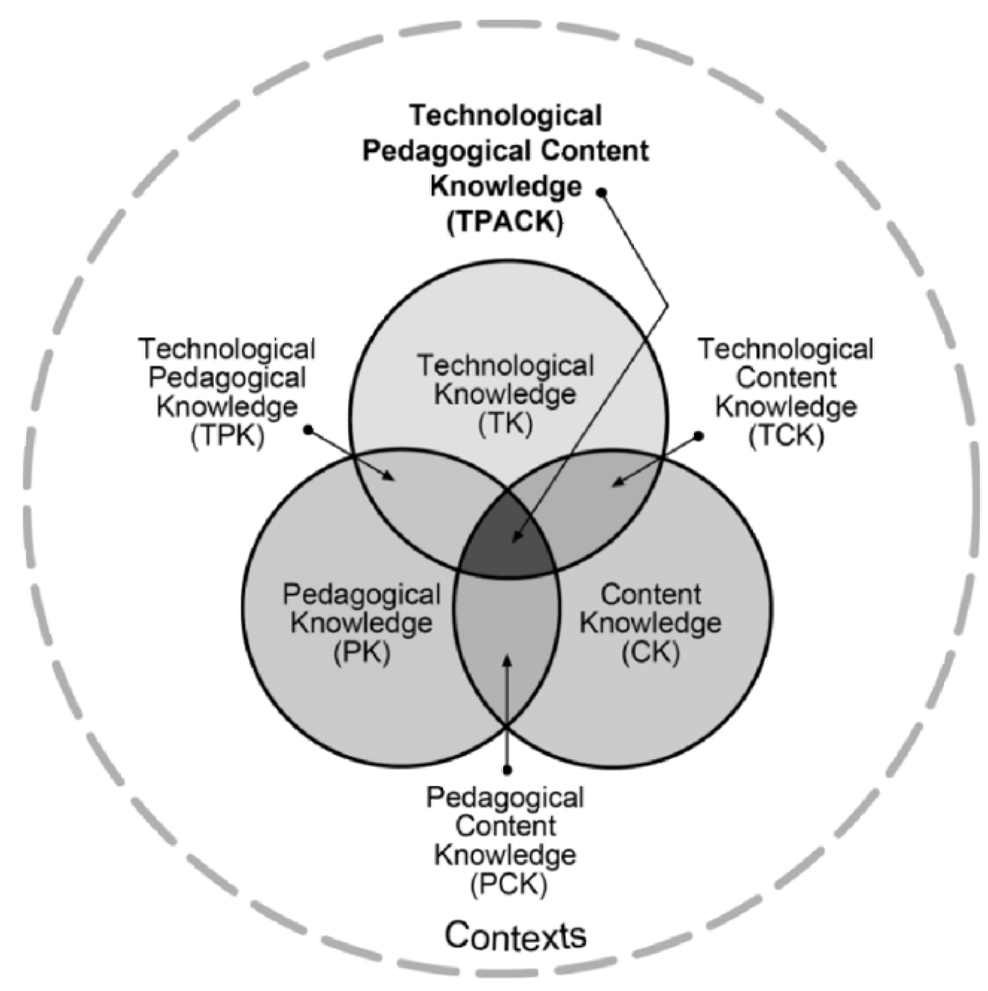

Gambar 1. Kerangka TPACK dan komponen-komponen pengetahuannya. Sumber:

Koehler \& Mishra (2009)

Dalam TPACK terdapat tujuh komponen pengetahuan. Tiga komponen merupakan basis pengetahuan inti yaitu content knowledge (CK), pedagogical 
knowledge (PK), dan technological knowledge (TK). Hubungan (relationship) di antara dua komponen (between) dan interaksi ketiga komponen (among) membentuk empat komponen pengetahan lainnya. Ketiga komponen pengetahun yang dihasilkan oleh hubungan antara dua komponen adalah technological pegadogical knowledge (TPK) yang merupakan hubungan antara pengetahuan pedagogi dan pengetahuan teknologi, technological content knowledge (TCK) berupa irisan antara pengetahuan materi pembelajaran dengan pengetahuan teknologi, pedagogical content knowledge (PCK) yang merupakan pengetahuan materi pembelajaran dan cara mengajarkannya. Komponen di tengah yang beririsan dengan ketiga komponen inti pengetahuan (konten, pedagogi dan teknologi) adalah technological pedagogical content knowledge atau yang disebut dengan TPACK.

TPACK merupakan kerangka menginegrasikan teknologi ke dalam pembelajaran yang dapat dipakai pada seluruh mata pelajaran secara umum. Lalu bagaimana Pendidikan Jasmani dapat memanfaatkannya? Padahal sebagaimana disampaikan dalam pendahuluan, Pendidikan Jasmani memiliki hubungan yang unik dengan teknologi jika dibandingkan dengan mata pelajaran lain. Beberapa penelitian telah menyinggung kerangka TPACK dan Pendidikan Jasmani (Krause et al., 2017; Scrabis-Fletcher, Juniu, \& Zullo, 2016; Juniu, 2011). Secara esensial kerangka TPACK menekankan pada pendidik untuk mengtahui bagaimana menggunakan teknologi, dan bagimana mengajarkan pelajaran menggunakan teknologi dalam proses pembelajaran. Roth (2014) mencoba menggunakan kerangka TPACK dalam rangka menunjukkan bahwa Pendidikan Jasmani merupakan salah satu educational setting terbaik untuk mengintegrasikan teknologi. 
Tabel 1. Kerangka TPACK dalam Pendidikan Jasmani. Diadaptasi dari:

Scrabis-Fletcher, Juniu, \& Zullo (2016) dan Roth (2014).

\begin{tabular}{lll}
\hline Tipe pengetahuan & Definisi operasional & $\begin{array}{l}\text { Contoh/ isu yang } \\
\text { berkaitan }\end{array}$ \\
\hline Content Knowledge & Pengetahuan tentang materi/konten & Belajar gerak, \\
(CK) & $\begin{array}{l}\text { Pendidikan Jasmani yang harus } \\
\text { diajarkan }\end{array}$ & \\
\hline Pedagogical Knowledge & Pengetahuan tentang proses dan & Gaya belajar, \\
(PK) & praktik atau metode pengajaran & manajemen kelas, \\
& Pendidikan Jasmani & desain instruksi \\
\hline Technology Knowledge & Pengetahuan tentang teknologi baik & Google forms, email, \\
(TK) & standar maupun canggih & aplikasi ponsel, dll. \\
\hline Pedagogical Content & Pengetahuan tentang bagaimana & Praktikum, instruksi, \\
Knowledge (PCK) & mengajarkan Pendidikan Jasmani & penugasan. \\
\hline Technological Content & Pengetahuan tentang teknologi dalam & Jump It App, running \\
Knowledge (TCK) & Pendidikan Jasmani & app berbasis GPS, dll. \\
\hline Technological & Pengetahuan tentang cara mengajar & Pemilihan teknologi \\
Pedagogical Knowledge & menggunakan teknologi & yang sesuai, cara kerja \\
(TPK) & & alat \\
\hline Technological & Memahami dan menggabungkan & Keberhasilan integrasi \\
Pedagogical Content & ketiga komponen: teknologi, & teknologi dalam \\
Knowledge (TPACK) & pengajaran, dan Pendidikan Jasmani & Pendidikan Jasmani \\
\hline
\end{tabular}

Seperti disinggung dalam artikel Eberline dan Richards (2013), perangkat seperti iPad menyediakan fasilitas untuk menerapkan teknologi dalam Pendidikan Jasmani. Manajemen kelas, rencana pelajaran, data siswa, dan jenis informasi lainnya dapat dikelola menggunakan iPad. Penggunaan lainnya adalah untuk merekam dan memutar ulang klip video. Guru dapat merekam video penampilan siswa dan kemudian memutar ulang video untuk menunjukkan kepada siswa elemen keterampilan yang mereka lakukan dengan benar dan elemen-elemen yang membutuhkan perbaikan. Video juga dapat digunakan untuk menyoroti siswa yang 
berhasil pada tugas tertentu, yang dapat secara positif memperkuat perilaku siswa. Studi tentang penggunaan teknologi dalam Pendidikan Jasmani pada umumnya diambil dari penelitian di Amerika Serikat. Akibatnya pada tingkat aplikasi secara teknis kadang ditemui ketidaksesuaian dengan konteks di tempat lain. Sebagai contoh, gawai yang sering dijadikan rujukan penggunaan teknologi dalam Pendidikan Jasmani di Amerika Serikat adalah iPad. Sementara di Indonesia, misalnya, lebih dikenal parangkat teknologi yang berbasis Android. Hal ini seharusnya tidak mengecoh para pendidik dalam mengaplikasikan teknologi pada proses pembelajaran. Contoh-contoh teknis penggunaan teknologi sebaiknya ditempatkan sebagai inspirasi alih-alih ditiru secara mutlak sehingga implementasi teknologi dalam Pendidikan Jasmani selalu berlandaskan integrasi teknologi secara konseptual.

\section{Teknologi dan penyiapan guru Pendidikan Jasmani}

Kembali pada konsensus GoFPEP 2010, selain dalam proses pembelajaran, penggunaan teknologi dalam Pendidikan Jasmani juga dikaitkan dengan penyiapan guru. Tugas menyiapkan guru terutama ada pada institusi perguruan tinggi yang memiliki latar belakang dan perhatian pada pedagogi. Sasaran respon Pendidikan Jasmani terhadap teknologi adalah mempromosikan penggunaan teknologi yang efektif untuk meningkatkan kesempatan belajar bagi para calon guru (Edginton et al., 2011), mempersiapkan lingkungan pembelajaran calon guru yang dapat memfasilitasi penggunaan teknologi (Juniu, 2011) dan persuasi sosial guna mencapai kepercayaan diri calon guru dalam memanfaatkan teknologi dalam pembelajaran (Krause, 2017).

Sebelum menuju pembahasan aplikasi teknologi yang efektif, menurut Griban et al. (2018) ada satu isu yang harus diperhatikan terlebih dahulu yaitu persoalan persepsi. Perkembangan teknologi kebugaran (fitness technologies) diramalkan akan 
membawa perubahan radikal dalam persepsi yang berlaku bagi guru Pendidikan Jasmani. Menurut mereka, di samping persyaratan guru Pendidikan Jasmani yang telah mapan secara tradisional, muncul kebutuhan yang mendesak untuk pembentukan kualitas profesional yang memenuhi tujuan pendidikan tinggi sekaligus menjawab tantangan inovasi teknologi modern.

Penanaman persepsi ini perlu dimulai sejak para calon pendidik mengenyam pendidikan atau sebagai calon guru (preservice teacher). Penanaman persepsi ini dilakukan pada lingkungan pendidikan tinggi dengan para pengajar sebagai pihak yang berperan penting. Temuan Scrabis-Fletcher et al. (2016) menunjukkan bahwa kerangka TPACK membantu untuk menggambarkan apa pengetahuan konten, pengetahuan pedagogis, dan pengetahuan teknologi spesifik yang diperlukan untuk memenuhi kebutuhan mahasiswa calon guru. Oleh karena itu pengajar di perguruan tinggi dituntut untuk sadar akan kerangka TPACK sehingga mereka dapat menunjukkan peluang-peluang integrasi teknologi dalam Pendidikan Jasmani melalui berbagai macam cara.

Berkaitan dengan teknologi dan penyiapan calon guru Pendidikan Jasmani, peran para pengajar di perguruan tinggi dapat dilihat dalam dua hal. Pertama, mereka memberi pemahaman kerangka integrasi teknologi dan pengajaran bagi calon guru seperti sudah dibahas sebelumnya. Kedua, mereka memanfaatkan teknologi itu sendiri untuk berkontribusi dalam pengembangan pengetahuan untuk memantapkan batang tubuh keilmuan (a tenable body of knowledge) Pendidikan Jasmani (Zeigler, 2014). Perkembangan teknologi informasi dan komunikasi serta pertumbuhan internet yang pesat merupakan peluang dalam mengakses pengetahuan. Teknologi komputer juga berpotensi dalam penyebaran pengetahuan untuk membantu calon guru sebagai seorang profesional. Pendidik harus memiliki pengetahuan, kompetensi, dan 
keterampilan yang diperlukan untuk memberikan layanan perkembangan aktivitas jasmani yang berkualitas kepada publik melalui sekolah. Pada peran yang kedua, teknologi dapat dilihat sebagai sesuatu yang aplikatif di luar konteks pengajaran secara khusus namun tetap memiliki kontribusi bagi penyiapan calon guru.

Setelah pembahasan pada area teori dan konsep, lalu bagaimana teknologi yang efektif untuk meningkatkan kesempatan belajar bagi para calon guru? Jawaban singkat muncul dari pernyataan Juniu (2011), "choose your technology to aid your teaching, rather than designing your lesson to fit the available technology." Teknologi yang efektif, menurutnya, berawal dari cara pandang dalam memilih teknologi yang membantu pengajaran, bukan merancang pelajaran agar sesuai dengan teknologi yang tersedia. Ketika hendak melangkah pada tataran aplikatif, cara pandang melalui kerangka teori menentukan efektivitas teknologi yang digunakan. Dengan demikian dalam mempersiapkan calon guru, teknologi sebagai alat saja tidak menjamin kualitas pendidikan. Cara pandang dan penguasaan atas kerangka teori dan konsep adalah yang pertama berperan (Mishra \& Koehler, 2006).

Dalam mempersiapkan calon guru, selain teknologi itu sendiri, ada setidaknya dua hal lain yang penting untuk dilakukan. Pertama adalah merancang pengalaman pendidikan yang dapat mendorong mahasiswa calon guru mengonstruksi pengetahuan. Kedua, membuat calon guru memahami dasar-dasar mengajar materi pelajaran saat mengintegrasikan teknologi. Hal ini kemudian menimbulkan pertanyaan: bagaimana calon guru mengembangkan hubungan teknologi, pedagogi dan konten untuk mengajar dalam disiplin mereka. Pertanyaan ini kembali berkaitan dengan pemahaman kerangka TPACK. Kuncinya terletak pada penyiapan guru Pendidikan Jasmani dengan lingkungan yang mendorong penggunaan teknologi inovatif melalui pengalaman langsung. Pengalaman belajar untuk calon guru tersebut 
harus menyentuh berbagai jenis teknologi, aspek pertimbangan pedagogis atas perangkat digital, serta pengajaran dan pembelajaran menggunakan teknologi. Selama mendapatkan pembelajaran melalui pengalaman ini, para calon guru mengeksplorasi berbagai aktivitas yang dapat digunakan dalam Pendidikan Jasmani, merancang pelajaran berbasis teknologi yang menyasar tujuan dan sasaran spesifik dalam kurikulum Pendidikan Jasmani, dan menerapkannya dalam praktik mengajar (Juniu, 2011).

Teknologi yang dapat meningkatkan pembelajaran siswa harus dimulai dengan guru yang merasa nyaman dan percaya diri dalam menggunakan teknologi. Hasil penelitian Krause, (2017) menginformasikan mengenai penilaian kemampuan seseorang guru untuk berhasil (self-efficacy) dalam mengintegrasikan teknologi pada tingkatan tertentu dipengaruhi oleh pengalaman (mastery experience), pengalaman secara tidak langsung (vicarious experience), dan persuasi sosial (social persuasion). Di perguruan tinggi, persuasi sosial ini dapat dilakukan dengan memasukkan rencana pengajaran yang memberi peluang bagi calon guru untuk merasakan pengalaman penguasaan teknologi dalam konteks pengajaran Pendidikan Jasmani. Persuasi sosial yang konstruktif dan secara teratur diberikan kepada calon guru mungkin juga membantu dalam membangun kepercayaan diri mereka (Krause, 2017). Ketika para calon guru sudah menjalani profesi sebagai guru, pengembangan profesional menjadi faktor utama dalam implementasi teknologi. Harapanya, setelah menginvestasikan waktu dan usaha untuk mempelajari teknologi, guru Pendidikan Jasmani dapat secara mahir menggunakan teknologi untuk persiapan rencana pelajaran, manajemen kelas, komunikasi dengan orang tua dan siswa, instruksi dan umpan balik, serta penilaian (Adkins et al., 2017). 
Integrasi teknologi dalam Pendidikan Jasmani tentu tidak terlepas dari hambatan. Brenner dan Brill (2016) menemukan hambatan paling kuat dalam integrasi teknologi yang diakui oleh guru-guru pada awal karir adalah terlalu banyak konten untuk dibahas, kurangnya waktu untuk membuat dan menerapkan pelajaran berbasis teknologi dan kurangnya perangkat lunak yang tersedia di sekolah. Hambatan yang berasal dari luar seperti lingkungan sekolah lebih besar daripada hambatan dari dalam berupa pengetahuan guru atau akses ke pengetahuan. Ini menunjukkan guru tidak bisa bekerja sendiri, dan perlunya dukungan lingkungan dalam upaya integrasi teknologi dalam Pendidikan Jasmani.

\section{Teknologi dalam advokasi hasil Pendidikan Jasmani}

Setelah menyasar integrasi dalam proses pembelajaran dan perannya dalam penyiapan guru, apakah teknologi dapat membantu mengadvokasi hasil (outcome) pembelajaran Pendidikan Jasmani? Sebagaimana pandangan Setiawan (2004), krisis identitas dan legitimasi dalam Pendidikan Jasmani berkaitan dengan skeptisisme terhadap outcome pembelajaran. Para pakar Pendidikan Jasmani di perguruan tinggi terlalu sibuk dengan klaim bahwa Pendidikan Jasmani mampu menjadi alat yang ampuh dalam membentuk karakter bangsa, moral, disiplin dan nilai positif lainnya, tetapi lupa untuk meneliti keampuhannya tersebut.

Pendidikan Jasmani dinilai berpotensi memberikan kontribusi kepada perkembangan generasi muda dalam domain fisik, sosial, afektif dan kognitif. Keuntungan yang diklaim oleh Pendidikan Jasmani ini tidak serta merta muncul, namun berkaitan erat dengan konteks dan berbagai variabel pedagogis lainnya (Bailey et al., 2009). Penelitian-penelitian untuk menunjukkan manfaat Pendidikan Jasmani yang sudah dilakukan mungkin mulai menjawab skeptisisme di atas, namun belum 
dikomunikasikan dengan baik. Temuan atas manfaat Pendidikan Jasmani secara umum tampak menggembirakan, namun tantangan berikutnya adalah bagaimana guru Pendidikan Jasmani mampu mengomunikasikan hasil program ini dengan cara yang berarti. Dalam hal ini teknologi dinilai dapat membantu mengadvokasi keuntungankeuntungan yang bisa didapatkan dari pembelajaran Pendidikan Jasmani (Krause et al., 2017). Salah satu keuntungan yang dapat diraih dari penggunaan teknologi dalam mengadvokasi manfaat Pendidikan Jasmani adalah dapat dicapainya akuntabilitas dengan lebih baik.

Mengomunikasikan hasil-hasil atau manfaat Pendidikan Jasmani, sekali lagi, bukan melalui klaim-klaim dalam jurnal atau buku melainkan dapat dimulai dengan penilaian yang akuntabel, objektif dan terukur. Guru Pendidikan Jasmani secara tradisional mengandalkan pengamatan (observasi) sebagai metode utama penilaian untuk menentukan hasil belajar siswa. Kini, kemajuan teknologi yang berkaitan dengan aktivitas fisik dapat memberikan hasil pengukuran yang lebih valid dan andal. Guru dapat secara efisien meringkas catatan proses pembelajaran siswa melalui tabel dan grafik. Hasil ini membantu guru dalam mendokumentasikan hasil belajar siswa dengan lebih baik. Berbekal data yang dikumpulkan melalui teknologi, guru Pendidikan Jasmani menjadi lebih siap ketika mencoba untuk meyakinkan berbagai pemangku kepentingan (diantaranya siswa, orang tua, kolega, dan pemerintah) mengenai manfaat dari program Pendidikan Jasmani yang diajarkannya (Eberline \& Richards, 2013). Klaim atas hasil Pendidikan Jasmani dengan demikian dapat dilihat secara lebih objektif berdasarkan data-data. Objektivitas ini pada gilirannya berpotensi memberikan dampak positif terhadap legitimasi Pendidikan Jasmani.

Seiring perkembangan konsep literasi jasmani, hasil Pendidikan Jasmani tidak terbatas hanya di sekolah. Advokasi atas hasil pembelajaran Pendidikan Jasmani 
ketika diletakkan dalam kerangka literasi jasmani dapat mempromosikan perkembangan manusia secara utuh. Sebagaimana pandangan Durden-Myers, Whitehead, dan Pot (2018), Pendidikan Jasmani memiliki potensi untuk mendorong upaya mewujudkan manusia yang utuh sepanjang hayat. Hal ini dapat menjadi landasan bagi arah identitas dan legitimasi Pendidikan Jasmani. Teknologi, dalam hal ini, dapat digunakan untuk mendorong literasi jasmani seperti mendokumentasikan hasil-hasil Pendidikan Jasmani yang objektif, dan mengomunikasikan literasi jasmani secara berkelanjutan.

\section{KESIMPULAN}

Terjadinya krisis identitas dan legitimasi dalam Pendidikan Jasmani, salah satunya, didorong oleh adanya desakan kemajuan teknologi. Dalam perkembangannya, teknologi dinilai telah menjadi standar bagi semua mata pelajaran dan dapat memberi peluang bagi peningkatan kualitas pembelajaran Pendidikan Jasmani. Integrasi teknologi dalam proses pembelajaran Pendidikan Jasmani dengan mempertimbangkan kerangka TPACK membuat desakan untuk menyelenggarakan mata pelajaran bermuatan teknologi dapat diakomodasi dalam mata pelajaran yang sudah eksis. Dengan kata lain, tidak perlu mata pelajaran khusus teknologi informasi. Teknologi secara integral dapat dipelajari dan diaplikasikan dalam pembelajaran Pendidikan Jasmani dan mata pelajaran lainnya. Dengan menggunakan teknologi secara konseptual, guru dapat meraih kembali fungsinya sebagai fasilitator pembelajaran Pendidikan Jasmani. Pada akhirnya integrasi teknologi dalam proses pembelajaran berdasarkan kerangka TPACK dan penyiapan guru dengan mempertimbangkan teknologi dinilai dapat meningkatkan hasil pembelajaran. Peluang untuk mengadvokasi dan mengomunikasikan hasil pembelajaran Pendidikan 
Jasmani juga bisa didapatkan dengan memanfaatkan teknologi. Ketika hal ini dilakukan, pada gilirannya dapat menjadi jalan bagi peneguhan identitas dan meligitimasi keberadaan Pendidikan Jasmani. Potensi ini tentu hanya bisa terwujud sebagai kenyataan dengan upaya yang sungguh-sungguh dari para pendidik di lingkungan Pendidikan Jasmani.

\section{DAFTAR PUSTAKA}

Adkins, M., Bice, M. R., Worrell, V., \& Unruh, N. (2017). Keeping the physical educator "connected": an examination of comfort level, usage and professional development available for technology integration in the curricular area of physical education. Contemporary Issues in Education Research, 10(4), 225230.

Bailey, R., Armour, K., Kirk, D., Jess, M., Pickup, I., \& Sandford, R. (2009). The educational benefits claimed for physical education and school sport: An academic review. Research Papers in Education, 24(1), 1-27. https://doi.org/10.1080/02671520701809817

Brenner, A. M., \& Brill, J. M. (2016). Investigating practices in teacher education that promote and inhibit technology integration transfer in early career teachers. TechTrends, 60, 136-144. https://doi.org/10.1007/s11528-016-0025-8

Durden-Myers, E. J., Whitehead, M. E., \& Pot, N. (2018). Physical literacy and human flourishing. Journal of Teaching in Physical Education, 37(3), 308-311. https://doi.org/https://doi.org/10.1123/jtpe.2018-0132

Eberline, A. D., \& Richards, K. A. R. (2013). Teaching with technology in physical education. Strategies: A Journal for Physical and Sport Educators, 26(6), 38-39. https://doi.org/10.1136/bmj.2.3073.689-a 
Edginton, C. R., Chin, M., Geadelmann, P. L., \& Ahrab-Fard, I. (2011). Revitalizing health and physical education in the 21 st century. Journal of Physical Education, Recreation \& Dance, $\quad 82(8), \quad 6-10$. https://doi.org/10.1080/07303084.2011.10598666

Griban, G., Prontenko, K., Zhamardiy, V., Zhamardiy, V., Tkachenko, P., Kruk, M., ... Zhukovskyi, Y. (2018). Professional stages of a physical education teacher as determined using fitness technologies. Journal of Physical Education and Sport, 18(2), 565-569. https://doi.org/10.7752/jpes.2018.02082

Juniu, S. (2011). Pedagogical uses of technology in physical education. Journal of Physical Education, Recreation \& Dance, 82(9), 41-49. https://doi.org/10.1080/07303084.2011.10598692

Koehler, M. J., \& Mishra, P. (2009). What is technological pedagogical content knowledge? Contemporary Issues in Technology and Teacher Education, 9(1), 60-70. https://doi.org/10.1016/j.compedu.2010.07.009

Krause, J. M. (2017). Physical education student teachers' technology integration selfefficacy. The Physical Educator, 74, 476-496. https://doi.org/10.18666/TPE2017-V74-I3-7329

Krause, J. M., Franks, H., \& Lynch, B. (2017). Current technology trends and issues among health and physical education professionals. Physical Educator, 74(1), 164-180. $\quad$ Retrieved from http://search.ebscohost.com/login.aspx?direct=true\&db=a9h\&AN=120914200\&s ite $=$ ehost-live

Mishra, P., \& Koehler, M. J. (2006). Technological pedagogical content knowledge: a framework for integrating technology in teacher knowledge. Teachers College Record, 108(6), 1017-1054. https://doi.org/10.1111/j.1467-9620.2006.00684.x 
Paramitha, S. T., \& Anggara, L. E. (2018). Revitalisasi pendidikan jasmani untuk anak usia dini melalui penerapan model bermain edukatif berbasis alam. Jurnal Pendidikan Jasmani Dan Olahraga, 3(1), 41-51. https://doi.org/10.17509/jpjo.v3i1.10612

Pyle, B. B., \& Esslinger, K. (2014). Utilizing technology in physical education: addressing the obstacles of integration. The Delta Kappa Gamma Bulletin, 80(2), 35-40. $\quad$ Retrieved from http://0ehis.ebscohost.com.brum.beds.ac.uk/eds/pdfviewer/pdfviewer?sid=7eedbd8e94ab-4ba4-9b45-f022515a86d6@sessionmgr114\&vid=4\&hid=102

Roth, K., Journal, K., \& Education, P. (2014). Technology for tomorrow's teachers. Journal of Physical Education, Recreation \& Dance, 84(4), 3-5. https://doi.org/10.1080/07303084.2014.884420

Scrabis-Fletcher, K., Juniu, S., \& Zullo, E. (2016). Pre-service physical education teachers' technological pedagogical content knowledge. The Physical Educator, 73(1), 704-718. Retrieved from http://ascilite.org.au/ajet/ajet28/semiz.html

Setiawan, C. (2004). Krisis identitas dan legitimasi dalam pendidikan jasmani. Jurnal Pendidikan Jasmani Indonesia, 1(1), 1-7. Retrieved from https://journal.uny.ac.id/index.php/jpji/article/viewFile/112/pdf

Zeigler, E. F. (2014). Fostering physical activity values in the world of the future. International Journal of Kinesiology and Sports Science, 2(2), 16-35. https://doi.org/10.7575/aiac.ijkss.v.2n.2p.16 